\title{
Seasonality, estrous cycle characterization, estrus synchronization, semen cryopreservation, and artificial insemination in the Pacific white-sided dolphin (Lagenorhynchus obliquidens)
}

\author{
T R Robeck ${ }^{1}$, K J Steinman ${ }^{1,2}$, M Greenwell ${ }^{3}$, K Ramirez $^{3}$, W Van Bonn ${ }^{3}$, M Yoshioka ${ }^{4}$, \\ E Katsumata $^{5}$, L Dalton ${ }^{6}$, S Osborn ${ }^{6}$ and J K O'Brien ${ }^{1,7}$
}

${ }^{1}$ SeaWorld and Busch Gardens Reproductive Research Center, Busch Entertainment Corporation, San Diego, California 92109, USA, ${ }^{2}$ Smithsonian Institution, Conservation and Research Center, National Zoological Park, Front Royal, Virginia 22630, USA, ${ }^{3}$ John G. Shedd Aquarium, Chicago, Illinois 60605, USA, ${ }^{4}$ Laboratory of Fish Culture, Graduate School of Bioresources, Mie University, Tsu, Mie 514-8507, Japan, ${ }^{5}$ Kamogawa SeaWorld, Kamogawa, Chiba 296-0041, Japan, ${ }^{6}$ SeaWorld San Antonio, San Antonio, Texas 78259, USA and ${ }^{7}$ Faculty of Veterinary Science, Centre for Advanced Technologies in Animal Genetics and Reproduction, University of Sydney, Sydney, New South Wales 2006, Australia

Correspondence should be addressed to T R Robeck; Email: todd.robeck@seaworld.com

\begin{abstract}
The reproductive physiology of the Pacific white-sided dolphin, Lagenorhynchus obliquidens, was characterized to facilitate the development of artificial insemination (AI) using cryopreserved spermatozoa. Specific objectives were to: 1) describe reproductive seasonality of the Pacific white sided dolphins; 2) describe urinary LH and ovarian steroid metabolites during the estrous cycle; 3) correlate LH and ovarian steroidal metabolite patterns to ultrasound-monitored follicular growth and ovulation; and 4) assess the efficacy of synchronizing estrus, sperm collection/cryopreservation, and intrauterine insemination. Ovulations $(64 \%, n=37)$ and conceptions $(83 \%, n=18)$ occurred from August to October. Peak mean serum testosterone ( $24 \mathrm{ng} / \mathrm{ml})$, cross-sectional testicular area $\left(41.6 \mathrm{~cm}^{2}\right)$, and sperm concentration $\left(144.3 \times 10^{7} \mathrm{sperm} / \mathrm{ml}\right)$ occurred in July, August, and September respectively. Spermatozoa were only found in ejaculates from July to October. Estrous cycles $(n=22)$ were $31 \mathrm{~d}$ long and were comprised of a $10 \mathrm{~d}$ follicular and $21 \mathrm{~d}$ luteal phase. Ovulation occurred $31.2 \mathrm{~h}$ after the onset of the LH surge and $19.3 \mathrm{~h}$ after the LH peak. Follicular diameter and circumference within $12 \mathrm{~h}$ of ovulation were 1.52 and $4.66 \mathrm{~cm}$ respectively. Estrus synchronization attempts with altrenogest resulted in $17(22 \%)$ ovulatory cycles with ovulation occurring $21 \mathrm{~d}$ post-altrenogest. Ten Al attempts using cryopreserved semen resulted in five pregnancies $(50 \%)$. The mean gestation length was 356 days (range 348-367). These data provide new information on the Pacific whitesided dolphin's reproductive physiology and collectively enabled the first application of $\mathrm{Al}$ in this species.

Reproduction (2009) 138 391-405
\end{abstract}

\section{Introduction}

Although a common species found throughout the northern Pacific, almost nothing is known about the reproductive physiology of the Pacific white-sided dolphin, Lagenorhynchus obliquidens. While these animals are prevalent in the wild (Hammond et al. 2008), few have been held in captivity. Out of the estimated 119 animals currently maintained in 23 zoos or aquaria around the world, only $10 \%$ of this population are residing in the USA. Despite the small numbers of animals held in USA aquaria, the majority of successful captive breeding (eight out of ten) has occurred in one USA facility with one male.
The successes that have been made through natural captive propagation are currently threatened by the lack of both available breeding males and cooperative genetic management practices among USA facilities. Inbreeding within small captive populations must be avoided to ensure long-term population health and enable the development of self-sustaining populations (Wildt 1992, Wildt et al.1997). Artificial insemination (Al) combined with semen cryopreservation tools may provide the vehicle necessary to avoid inbreeding depression within this captive population. However, information on the basic reproductive function of the species must be obtained before such assisted reproductive technologies can be implemented. 
Previous efforts towards describing the reproductive biology of this species have relied exclusively on postmortem analysis of reproductive tracts from animals caught as bycatch in fisheries or that died in captivity (Harrison et al. 1972, Harrison \& McBrearty 1977, Walker et al. 1986, Ferrero et al. 1993, Ferrero \& Walker 1996). Based on the presence of at least one corpus luteum, females reach sexual maturation at around 11 years of age and $170 \mathrm{~cm}$ in length. Conception occurs from June to August with an 11-month gestation (Harrison et al. 1972, Ferrero et al. 1993). Males reach sexual maturity at $170-180 \mathrm{~cm}$ from 10 to 11 years of age and exhibit seasonal changes in spermatogenesis (Harrison et al. 1972, Ferrero \& Walker 1996).

Real-time evaluation of living animals is required to move beyond this basic biological information collected from post-mortem data. Analysis of urinary reproductive hormones combined with ovarian ultrasound exams has resulted in describing both follicular dynamics and hormonal profiles during estrous cycles and the periovulatory period in killer whale (Walker et al. 1988, Robeck et al. 1993, 2004), bottlenose dolphin (Robeck et al. 2005b), and beluga (Steinman et al. 2007). The description of the periovulatory period allowed for the development of methods for consistent prediction of ovulation. Ovulation prediction combined with insemination trials enabled the development of consistently repeatable methods for $\mathrm{Al}$ in these three cetacean species (Robeck et al. 2004, 2005b, O'Brien et al. 2008). Despite these successes in other cetaceans, virtually no data have been published on hormone profiles and follicular dynamics of the Pacific white-sided dolphin.

In addition to ovulation prediction, methods for ovulation control or estrus synchronization allow for practical application of $\mathrm{Al}$ to any species. Altrenogest has been used as both a contraceptive agent and to synchronize estrus for $\mathrm{Al}$ in the killer whale, bottlenose dolphin (Young \& Huff 1996, Robeck et al. 2004, 2005b, O'Brien \& Robeck 2006), and beluga (Robeck et al. 2007, O'Brien et al. 2008). Application of this technique for ovulation manipulation in the Pacific white-sided dolphins, if successful, would allow for improved management of natural breeding and for synchronizing estrus for Al.

Semen cryopreservation combined with Al enables long-term genetic management, since valuable male gametes, particularly from founder animals, can be reintroduced into the population long after the male's normal reproductive contribution (Wildt 1992, Wildt et al. 1997). This approach also maximizes the global genetic exchange of gametes among ex situ populations, but semen cryopreservation methods must be optimized for Al to reach its full potential as a management tool. Methods for semen cryopreservation have been developed for three cetacean species, the bottlenose dolphin, the killer whale, and the beluga (Seager et al. 1981, Schroeder \& Keller 1990, Robeck \& O'Brien 2004,
Robeck et al. 2004, 2005a, 2005b, O’Brien \& Robeck 2006, 2007). Despite their accessibility in captivity, no information is available concerning semen production or cryopreservation in the Pacific white-sided dolphin.

The overall goal of this research was to gain a sufficient level of understanding of the Pacific white-sided dolphin's reproductive physiology to develop Al using cryopreserved semen. To accomplish this, specific objectives were to: 1) describe reproductive seasonality in captive male and female Pacific white-sided dolphins; 2) determine the excretory dynamics of urinary LH and ovarian steroid metabolites during the estrous cycle; 3) correlate $\mathrm{LH}$ and ovarian steroidal metabolite patterns to ultrasound-monitored follicular growth and ovulation; and 4) assess the efficacy of synchronizing estrus, sperm collection/cryopreservation, and intrauterine insemination.

\section{Results \\ Seasonality}

Female

Based on profiles of serum progesterone $(\mathrm{P})$, a total of 37 ovulations ( $n=8$ females) resulting in 17 conceptions were observed from 1980 to 2001 (Table 1). Twenty-four out of 37 ovulations (64.7\%) and 14 out of 17 conceptions (82\%) occurred from August to October (Fig. 1).

Male

Mean monthly testosterone $(\mathrm{T})$ concentrations peaked in July $(24.3 \pm 1.3 \mathrm{ng} / \mathrm{ml} ; n=52)$ and were greater $(P<0.05)$ than the mean value from every other month of the year (range: February $0.09 \pm 0.02 \mathrm{ng} / \mathrm{ml}, n=6$, to June $5.6 \pm 3.8 \mathrm{ng} / \mathrm{ml}, n=7$; Fig. 1). Peak cross-sectional testicular area occurred in July and August, with the largest size occurring in August $\left(41.6 \pm 7.2 \mathrm{~cm}^{2}\right.$; Fig. 1). Testicular cross-sectional area in August was larger $(n=32 ; P<0.05)$ than every month except July $(36.2$ $\pm 10.7 \mathrm{~cm}^{2}$ ). The stromal parenchyma remained a homogeneous stippled appearance with a well-defined mediastinum and an oval cross-sectional shape throughout the year. However, relative to the echotexture of the hypaxialis lumborum muscle (HLM), the overall testicular echotexture gradually changed from slightly iso- to hypoechoic during nadir diameter months (January and February) to hyperechoic during months of maximal testosterone excretion (June-September; Fig. 2). Maximum hyperechogenicity subjectively appeared to correlate with maximum cross-sectional testicular diameter; while maximum hypoechogenicity was observed in conjunction with minimum testicular diameter (Fig. 2).

While differences $(P<0.05)$ between the mean amounts of ejaculate collected each month existed, no correlation between amount of ejaculate collected and 
Table 1 Description of animals used and samples collected during the study.

\begin{tabular}{|c|c|c|c|c|c|c|}
\hline Animal & Facility $^{\mathrm{a}}$ & Sex & Birth date & Weight $(\mathrm{kg})$ & Reproductive history ${ }^{b}$ & Contribution $^{c}$ \\
\hline 1 & SWT & $\mathrm{F}$ & $1976^{d}$ & 104 & Three abortions & $\mathrm{P}, \mathrm{US}$ \\
\hline 2 & SWT & $\mathrm{F}$ & $1978^{d}$ & 124 & Two calves, one abortion & $\mathrm{P}, \mathrm{US}$ \\
\hline 3 & SWT & $\mathrm{F}$ & $1980^{\mathrm{d}}$ & 131 & One calf & $P$, US \\
\hline 4 & SWT & $\mathrm{F}$ & & & & \\
\hline 5 & SWT & $\mathrm{F}$ & $1978^{d}$ & 118 & Four calves & $\mathrm{P}, \mathrm{US}, \mathrm{UH}, \mathrm{ES}, \mathrm{AI}$ \\
\hline 6 & SWT & $\mathrm{F}$ & $09 / 1993^{\mathrm{e}}$ & 127 & One calf & $\mathrm{P}, \mathrm{US}, \mathrm{UH}, \mathrm{ES}, \mathrm{AI}$ \\
\hline 7 & SWT & $\mathrm{F}$ & $1979^{d}$ & 129 & Four calves & $\mathrm{P}, \mathrm{US}, \cup \mathrm{H}, \mathrm{ES}, \mathrm{AI}$ \\
\hline 8 & SWT & $\mathrm{F}$ & $10 / 1996^{\mathrm{e}}$ & 107 & One calf & $\mathrm{P}, \mathrm{US}, \mathrm{UH}, \mathrm{ES}$ \\
\hline 9 & Shedd & $\mathrm{F}$ & $1985^{d}$ & 90 & Nulliparous & $\mathrm{P}, \mathrm{US}, \mathrm{UH}, \mathrm{ES}$ \\
\hline 10 & Shedd & $\mathrm{F}$ & $1988^{\mathrm{d}}$ & 123 & Nulliparous & $\mathrm{P}, \mathrm{US}, \mathrm{UH}, \mathrm{ES}$ \\
\hline 11 & Shedd & $\mathrm{F}$ & $1988^{d}$ & 91 & Nulliparous & $\mathrm{P}, \mathrm{US}, \mathrm{UH}, \mathrm{ES}, \mathrm{AI}$ \\
\hline 12 & Shedd & $\mathrm{F}$ & $1988^{\mathrm{d}}$ & 101 & Nulliparous & $\mathrm{P}, \mathrm{US}, \mathrm{UH}, \mathrm{ES}, \mathrm{AI}$ \\
\hline 13 & Shedd & $\mathrm{F}$ & $1988^{\mathrm{d}}$ & 86 & Nulliparous & $\mathrm{P}, \mathrm{US}, \mathrm{UH}, \mathrm{ES}, \mathrm{Al}$ \\
\hline 1 & SWT & M & $1978^{d}$ & 154 & Sired 12 calves & Seasonality \\
\hline 2 & KSW & M & $1983^{d}$ & 140 & No sired calves & Cryopreserved semen \\
\hline 3 & KSW & M & $1991^{d}$ & 120 & One sired calf & Cryopreserved semen \\
\hline
\end{tabular}

P, serum progesterone; US, ultrasound exam; UH, urinary hormones; $\mathrm{ES}$, estrous synchronization; $\mathrm{Al}$, artificial insemination.

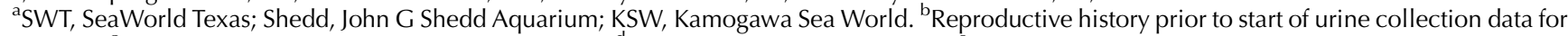
animals. ${ }^{\mathrm{C}}$ Data that the animal contributed to the study. ${ }^{\mathrm{d}}$ Estimated age for wild caught. ${ }^{\mathrm{e}}$ Captive born.

the presence of spermatozoa $(P>0.05)$ was detected. Ejaculates containing spermatozoa were only found from July to October. Both mean concentration and total spermatozoa per ejaculate in September (1443.0 $\pm 776.4 \times 10^{6}$ spermatozoa $\left./ \mathrm{ml}\right)$ were significantly
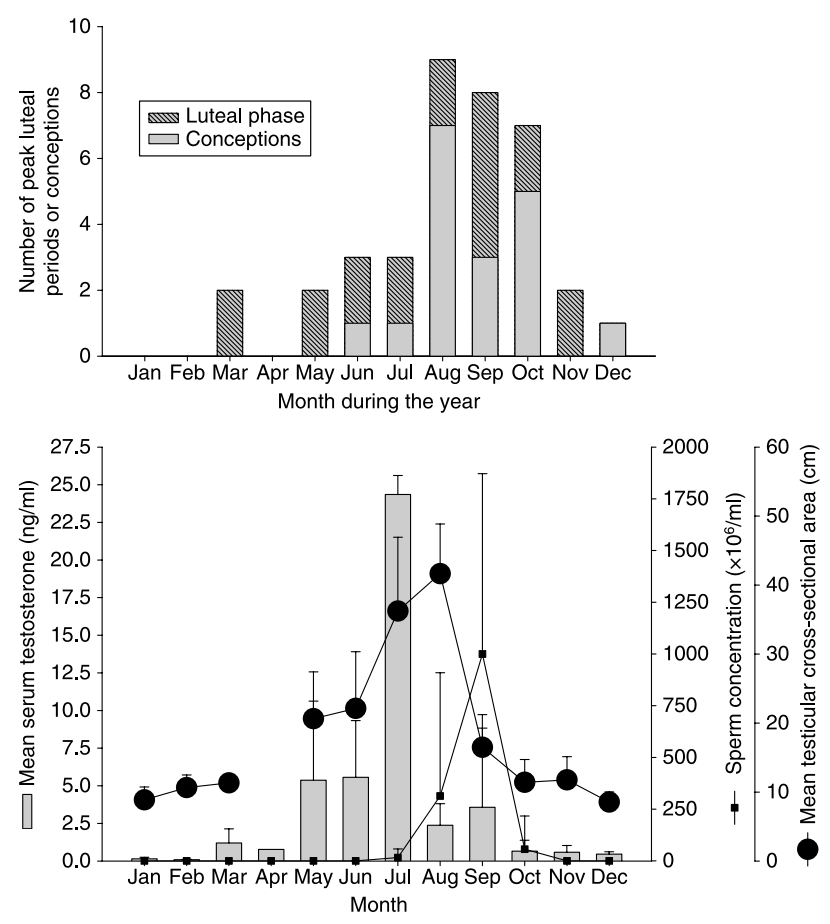

Figure 1 Demonstrates seasonal variations in female (top graph) and male (lower graph) reproductive parameters. For the female $(n=7)$, the bar charts illustrate frequency of luteal activity and conceptions. For the male $(n=1)$, profiles mean monthly serum testosterone $(n=52)$, sperm concentration $(n=290)$, and testicular cross-sectional area $(n=32)$ as determined by ultrasonography. greater $(P<0.05)$ than July $\left(86.0 \pm 57.3 \times 10^{6}\right.$ spermatozoa $/ \mathrm{ml})$, August $\left(647.8 \pm 737.1 \times 10^{6}\right.$ spermatozoa $\left./ \mathrm{ml}\right)$, or October (394.3 $\pm 202.9 \times 10^{6}$ spermatozoa/ml; Fig. 1$)$.

\section{Endocrine monitoring}

Hormone (estrogen conjugates $(\mathrm{EC}), \mathrm{LH}$, and urinary progestins (UP)) profiles during the periovulatory interval of 7 natural cycles and 15 post-altrenogest cycles were monitored during the study interval. Four out of the seven natural cycles occurred as repeat cycles after the animals (females 7, 5, and 8) had a non-conceptive postaltrenogest cycle. Female 13 cycled twice during a season without altrenogest pre-treatment. Based on continuously elevated progesterone and the presence of a CL (as determined by ultrasonography), female 11 had a retained $C L$ post ovulation (August 18, 2002) for 86 days in 2002 and again post Al (August 16, 2003) without any ultrasound evidence of pregnancy for 103 days in 2003. The mean interval between successive EC and LH peaks $(n=5)$ was $31.0 \pm 1.9$ and $30.9 \pm 1.7 \mathrm{~d}$ respectively. The luteal phase between successive ovulations was $20.8 \pm 2.4 \mathrm{~d}$.

For natural and synchronized estrous cycles, the mean length of the follicular phase and luteal phase was $10.0 \pm 2.4 \mathrm{~d}$ ( $n=22$, range: $7-14 \mathrm{~d}$ ) and $20.8 \pm 2.4 \mathrm{~d}$ ( $n=9$, range: $17-24 \mathrm{~d}$ ) respectively. The preovulatory EC rise was $3.2 \pm 1.0 \mathrm{~d}(n=22$, range: $1-6 \mathrm{~d})$. The interval between peak EC and peak LH was $16.7 \pm 12.8 \mathrm{~h}$ $(n=12$, range: $0-31 \mathrm{~h})$. The interval from the onset of the $\mathrm{LH}$ surge to peak $\mathrm{LH}$ was $13.4 \pm 4.8 \mathrm{~h}(n=7$, range: 8.0-18 h). The LH surge duration was $27.9 \pm 3.1 \mathrm{~h}(n=6$, range, $24-29 \mathrm{~h}$ ). Peak EC and $\mathrm{LH}$ concentrations were $14.5 \pm 13.0 \mathrm{ng} / \mathrm{mg} \mathrm{Cr}(n=22$, range: $3.8-62.7 \mathrm{ng} / \mathrm{mg} \mathrm{Cr})$ 

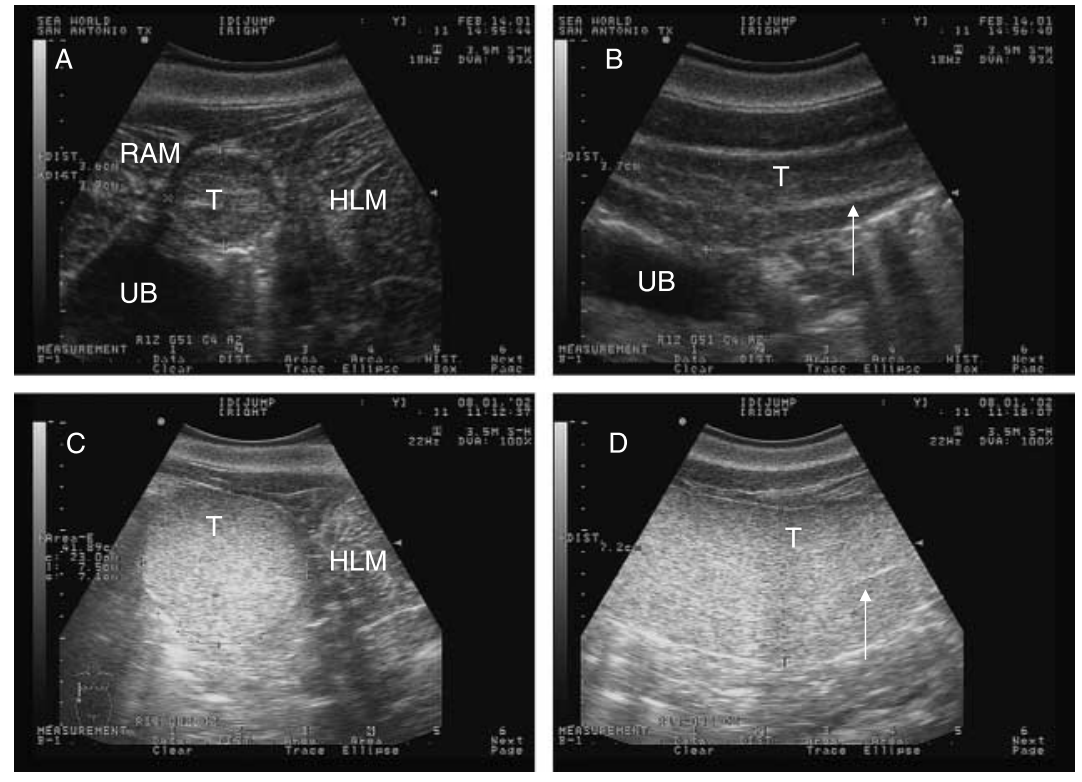

Figure 2 Transverse (A and $\mathrm{C}$ ) and longitudinal (B and D) ultrasounds images of the testes in an adult Pacific white-sided dolphin, Lagenorhynchus obliquidens, during February (A and B) and August (C and D) of the same year. HLM, hypaxialis lumborum muscle; RAM, rectus abdominus muscle; T, testis; UB, urinary bladder. Scale for all images is in centimeters. and $206.7 \pm 174.4 \mathrm{ng} / \mathrm{mg} \mathrm{Cr} \quad(n=22$, range: $32.2-$ $672 \mathrm{ng} / \mathrm{mg} \mathrm{Cr}$ ) respectively. The interval between peak $\mathrm{LH}$ and the first discernable post-ovulatory increase in UP was $1.8 \pm 1.0 \mathrm{~d}(n=17$, range: $1-4 \mathrm{~d})$. Hormone data from all animals were combined using day 0 as day of the peak $\mathrm{LH}$ to develop a composite dolphin estrous cycle (Fig. 3).

The canine $\mathrm{LH}(\mathrm{cLH})$ test empirical colorimetric descriptions when corresponding to the quantitative $\mathrm{LH}(\mathrm{qLH})$ test were as follows: slightly visible: 2.6 $\pm 0.5 \mathrm{ng} / \mathrm{ml}$; slightly less than: $15.5 \mathrm{ng} / \mathrm{ml}$; equal to: $34.7 \mathrm{ng} / \mathrm{ml}$; slightly greater than: $53.4 \pm 5.7 \mathrm{ng} / \mathrm{ml}$; or maximal: $88.6 \pm 10.0 \mathrm{ng} / \mathrm{ml}$. Results also demonstrated that subjective creatinine $(\mathrm{Cr})$ concentrations based on urine color (low, medium, and high) were comparable with concentrations determined using the quantitative assay (low: $0.22 \pm .03 \mathrm{mg} \mathrm{Cr}$; medium: $0.25 \pm 0.03 \mathrm{mg}$ Cr; high: $0.78 \pm 0.07 \mathrm{mg} \mathrm{Cr}$ ).

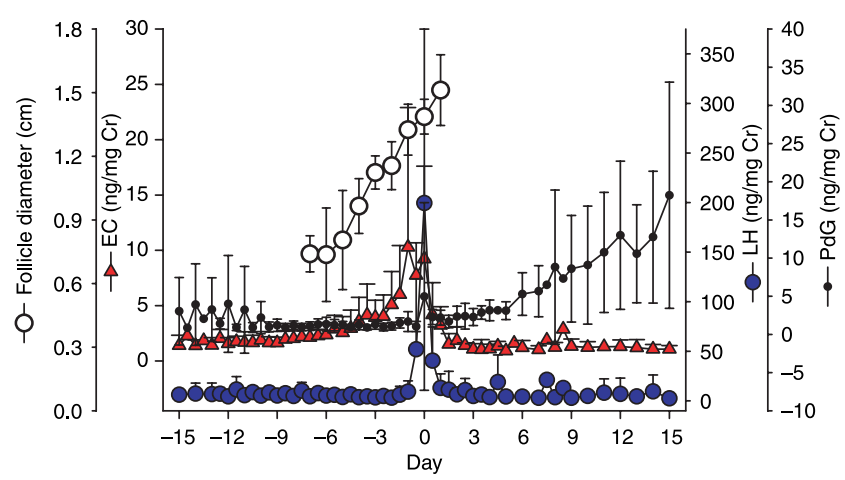

Figure 3 Mean values of the Pacific white-sided dolphin estrous cycle components, including urinary concentrations of EC $(n=12), \mathrm{LH}$ $(n=12)$, UP $(n=9)$, and normal primary follicle growth.

\section{Estrous synchronization and follicular recruitment}

Out of the 76 altrenogest treatments, 17 (22\%) resulted in subsequent ovulation. Three of the females accounting for 19 treatments never ovulated in response to altrenogest or on their own. If such females are removed from analyses, the remaining six females responded $30 \%$ (17 ovulations/57 treatments) of the time. For the females that responded to synchronization, the mean time from the end of altrenogest treatment to the beginning of the follicular phase, the LH surge, and ovulation were $15.2 \pm 5.5 \mathrm{~d}(n=17$, range: $7-22 \mathrm{~d})$, $20.6 \pm 4.4 \mathrm{~d}$ ( $n=17$, range: $14-29)$, and $21.6 \pm 4.4 \mathrm{~d}$ ( $n=17$, range: $15-30$ ) respectively. Out of the 76 altrenogest treatments, 18 were repeat treatments within the same year in females that did not respond to the first round or in one case where the animal (female 12) ovulated but was not inseminated. Ten ovulations $(17 \%$, 10 out of 58 total first treatments) occurred after the first round of altrenogest treatments, while six ovulations $(27 \%, 6$ out of 22) occurred after a second round of treatment, with female 12 ovulating after both the first and second treatments. Out of the 22 total ovulations, 5 $(23 \%)$ were repeat ovulations that occurred spontaneously after the first altrenogest induced ovulation of that season.

\section{Ultrasonographic evaluation of ovaries}

Location and general appearance of ovaries were similar to what has previously been described for bottlenose dolphins and the Indo-Pacific dolphins (Brook 2001, Brook et al. 2004). As with these other species, the ovaries were ovoid in appearance with a relatively hyperechoic hilus and hypoechoic cortex (Fig. 4). In ten 

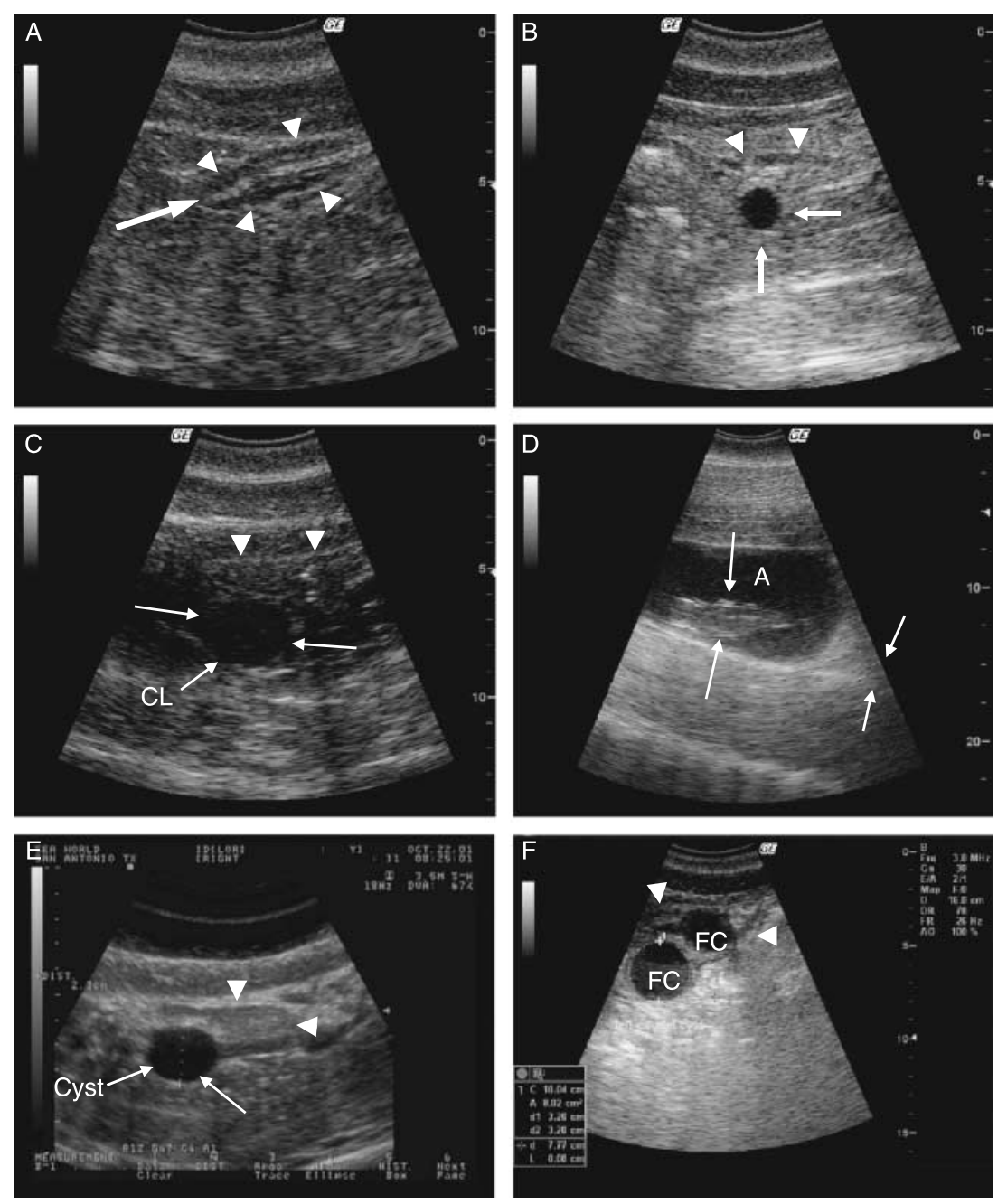

Figure 4 The Pacific white-sided dolphin ovarian (white arrow heads in all images) and uterine ultrasonography images. (A) Normal ovary with hypoechoic cortex and hyperechoic ovarian hilus (large arrow); (B) a round, turgid preovulatory follicle with thickened wall (long arrows); (C) a corpus luteum (CL: long arrows) of pregnancy; (D) day 87 pregnancy with amniotic fluid (A) and the fetus (white arrows); (E) ovarian cyst (white arrows); and (F) cystic follicles (FC). females, multiple ultrasonographic measurements of the length and width of the right $(n=24)$ and left ovaries $(n=36)$ were $4.71 \pm 0.8$ by $1.6 \pm 0.2 \mathrm{~cm}$ and $4.72 \pm 0.9$ by $1.8 \pm 0.3 \mathrm{~cm}$ respectively. No significant differences between the sizes of the right and left ovaries were detected $(P>0.05)$.

The mean number of days required for the eventual preovulatory follicle (POF) to develop from a diameter of 0.8 and $1.0 \mathrm{~cm}$ to ovulation was $6.3 \pm 1.3 \mathrm{~d}(n=10)$ and $4.8 \pm 1.1 \mathrm{~d}(n=12)$ respectively. The daily growth rate in circumference and diameter from 6 days prior to and until ovulation was 0.41 and $0.12 \mathrm{~cm} / \mathrm{d}$ respectively (Figs 3 and 5). The POF maximum circumference and diameter were $4.66 \pm 0.50 \mathrm{~cm}(n=16$, range: $4.15-5.70)$ and $1.52 \pm 0.16 \mathrm{~cm} \quad(n=16$, range: $1.25-1.83 \mathrm{~cm})$ respectively. The POF consistently became round prior to ovulation and was located on the left ovary $100 \%$ of the time.

Secondary follicles at the time of ovulation on the ipsilateral ovary $(n=4)$ to the POF were observed in $31 \%$ of the examinations (Fig. 5). In addition, two of these females had two tertiary follicles $>0.5 \mathrm{~cm}$ in diameter. The maximum diameter of secondary follicles was $1.18 \pm 0.19 \mathrm{~cm}$. While ovulations occurred exclusively on the left ovary, small follicles $(0.5-0.8 \mathrm{~cm})$ were often (not quantified) observed on the right or left ovary prior to the development of a dominant follicle. All the secondary and tertiary follicles on the right ovary, and most on the left ovary, regressed well before ovulation (Fig. 5).

Female 3 consistently had multiple $(n>5)$ follicles, $0.5-1.0 \mathrm{~cm}$ in diameter, on both ovaries throughout the year. Despite the persistence of the 'cystic' ovarian structures, the female became pregnant through natural breeding. Female 7 had a large $2.0 \mathrm{~cm}$ cyst on her right ovary that was first observed in 1999 and remained unchanged throughout the study (Fig. 4).

The time of ovulation as determined by ultrasonography occurred $35.8 \pm 9.2,31.2 \pm 8.6$, and $19.4 \pm 6.6 \mathrm{~h}$ after peak EC, LH surge onset, and peak $\mathrm{LH}$ respectively (Fig. 5). All pregnancies could be confirmed by ultrasonography between 6 and 8 weeks post Al. 


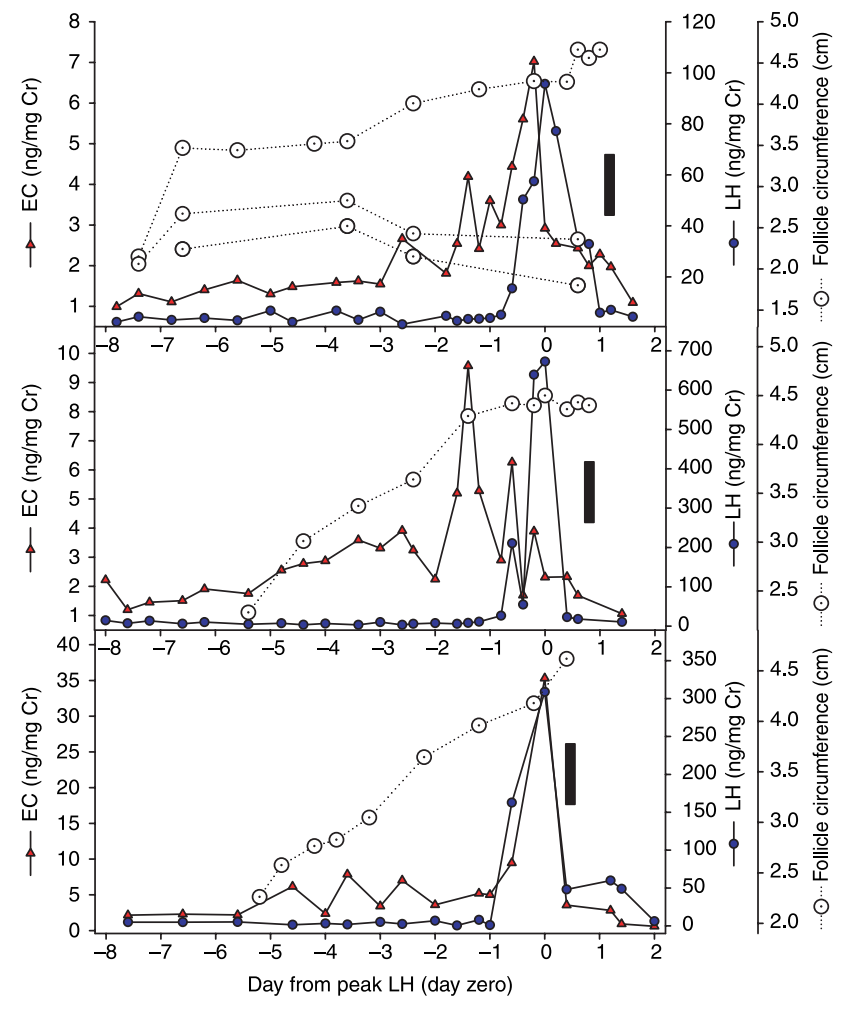

Figure 5 Follicular growth of primary and secondary follicles (top panel only) in three animals in relationship to urinary EC and LH. The black bar represents ovulation as determined by ultrasonography.

\section{Ejaculate characteristics of raw and post-thawed sperm used during the Al trials}

Owing to the over representation of male 1 in the US population, only ejaculates collected from male 2 and 3 were used for Al. The characteristics of these ten ejaculates are shown in Table 2. Overall, ejaculates from both males were of high quality with progressively motile (PM) spermatozoa and viability both $>88 \%$. For the straw-freezing method, total motility (TM), PM, and viability were all well maintained during the cryopreservation/thawing process $(48,47$, and $64 \%$ of initial characteristics respectively; Table 2). For the directional freezing method, high levels of TM, PM, and viability were retained following cryopreservation/thawing (94.0, 91.6, and $99.5 \%$ of initial characteristics respectively).

\section{Artificial inseminations}

Al was performed in five females during ten estrous cycles from September 2001 to October 2008 (Table 3). During the development of $\mathrm{Al}$, initial attempts (2001) relied on the presence of POFs after the animals had been administered altrenogest. As we developed both improved methods for semen deposition (uterine versus cervical) and increasingly rapid and accurate methods for determining urinary $\mathrm{EC}$ and $\mathrm{LH}$ concentrations, we were able to decrease the number of inseminations prior to ovulation and increase the $\mathrm{Al}$ success rate (Table 3 ).

For all Al trials, the mean number of inseminations per cycle was $1.9 \pm 1.5$. The overall conception rate (five total conceptions/ten estrus periods $\times 100$ ) was $50 \%$. However, if the first two attempts where semen was placed in the cervix are omitted, the conception rate (five total conceptions/eight estrus periods $\times 100$ ) was $63 \%$. Four out of the five conceptions occurred after an altrenogest synchronization treatment. The lowest dose of frozen-thawed PM spermatozoa that resulted in conception was $26.6 \times 10^{7}$ spermatozoa, and the mean dose (only the last insemination closest to ovulation was used if multiple inseminations per estrus were preformed) for conceptive and non-conceptive inseminations were $184.7 \pm 117.0 \times 10^{7}$ and $111.98 \pm 71.2$ $\times 10^{7}$ spermatozoa respectively. The mean time from Al to ovulation in conceptive and non-conceptive cycles was $-6.0 \pm 3.8 \mathrm{~h}$ (range: $-9.5-2.5 \mathrm{~h}$ ) and $-6.4 \pm 8.2 \mathrm{~h}$ (range: $-15.2-4 \mathrm{~h}$ ) respectively.

Females 7, 12, 13, and 6 delivered their calves 367, 358,354 , and 348 (mean $356.7 \pm 8.0$ d) days post $\mathrm{Al}$ respectively. As of March 4, 2009, female 6 has an ultrasonographically normal 164-day-old fetus.

\section{Discussion}

The Pacific white-sided dolphin, one of the six species in the genus Lagenorhynchus, is found throughout the coastal regions of the Northern Pacific Rim from Baja California to the Sea of Japan and Taiwan (Walker et al. 1986). Although the species is relatively abundant by International Union for Conservation of Nature (IUCN; Hammond et al. 2008) estimates, the basic reproductive biologic data required to judge the potential for a species to withstand external pressures are lacking. However, their relative abundance places the species in an ideal situation where current ex situ reproductive research efforts may be employed if future environmental conditions threaten their survival. For example, the recent extinction of the Baiji (Lipotes vexillifer) could not be prevented because ex situ reproductive research efforts were delayed until the species was already critically endangered (Turvey et al. 2007). Thus, with no history of successful ex situ breeding or even a basic understanding of that species' biology, little could be done to prevent their demise.

In addition to developing an understanding of normal reproductive physiology of an ex situ population, more intensive management tools, like gamete cryopreservation and $\mathrm{Al}$, can be developed to help maintain and possibly help preserve critically endangered species. In an effort towards reaching this goal, this research has used endocrine monitoring, with serum and urine, to characterize a range of reproductive events including reproductive seasonality, preovulatory follicular development, 
Table 2 Characteristics of the Pacific white-sided dolphin semen used for artificial insemination.

\begin{tabular}{|c|c|c|c|c|c|}
\hline Parameter & $\begin{array}{l}\text { Neat ejaculate male } \mathbf{2}^{\mathrm{a}} \\
\qquad(n=10)\end{array}$ & $\begin{array}{l}\text { Neat ejaculate male } 3^{\text {a }} \\
(n=5)\end{array}$ & $\begin{array}{c}\text { Post-thaw male } 2 \\
(0 \mathrm{~h}, n=18)\end{array}$ & $\begin{array}{l}\text { Post-thaw male } 3 \\
(0 h, n=5)\end{array}$ & $\begin{array}{c}\text { Post-thaw male } 3 \\
(0 \mathrm{~h}, n=2)\end{array}$ \\
\hline Freezing method & & & Straw/LN 2 & Straw/LN ${ }_{2}$ & $\mathrm{DS}^{\mathrm{b}}$ \\
\hline \multicolumn{6}{|l|}{ Semen characteristics } \\
\hline Volume (ml) & $5.51 \pm 4.8$ & $9.8 \pm 3.6$ & $11.5 \pm 5.4^{\mathrm{c}}$ & $14.0 \pm 7.0^{c}$ & $8.8 \pm 1.1^{\mathrm{c}}$ \\
\hline $\begin{array}{l}\text { Sperm concentration } \\
\left(\times 10^{7} / \mathrm{ml}\right)\end{array}$ & $71.3 \pm 45.9$ & $53.7 \pm 33.0$ & $25.3 \pm 11.9$ & $18.7 \pm 3.5$ & $19.5 \pm 7.0$ \\
\hline $\begin{array}{l}\text { Total spermatozoa } \\
\text { per ejaculate } \\
\left(\times 10^{7} / \mathrm{ml}\right)\end{array}$ & $319.1 \pm 09.1$ & $614.0 \pm 605.6$ & $129.7 \pm 102.6$ & $249.3 \pm 82.7$ & $171 \pm 26.8$ \\
\hline \multicolumn{6}{|l|}{ Sperm characteristics } \\
\hline Total motility & $95.3 \pm 4.6$ & $88.0 \pm 4.5$ & $50.8 \pm 9.1$ & $42.5 \pm 10.6$ & $82.5 \pm 3.5$ \\
\hline $\begin{array}{l}\text { Percent progressive } \\
\text { motility }\end{array}$ & $98.1 \pm 1.2$ & $98.8 \pm 0.4$ & $96.2 \pm 2.2$ & $96.5 \pm 2.1$ & $96.5 \pm 2.1$ \\
\hline Progressive motility & $93.5 \pm 4.6$ & $87.0 \pm 4.8$ & $48.9 \pm 9.2$ & $40.9 \pm 9.3$ & $79.7 \pm 5.2$ \\
\hline Kinetic rating $(0-5)^{\mathrm{d}}$ & $5 \pm 0$ & $5 \pm 0$ & $4.1 \pm 0.7$ & $4.6 \pm 0.1$ & $4.6 \pm 0.1$ \\
\hline Sperm motility index & $467.5 \pm 4.9$ & $434.8 \pm 24.0$ & $202.3 \pm 50.7$ & $185.8 \pm 39.6$ & $366.7 \pm 35.0$ \\
\hline Viability $(\%)$ & $88.4 \pm 1.91$ & $92.2 \pm 3.0$ & $70.2 \pm 11.8$ & $59 \pm 5.7$ & $91.8 \pm 0.4$ \\
\hline
\end{tabular}

Values are means \pm s.D.

${ }^{\mathrm{a}} \mathrm{A}$ total of ten ejaculates were cryopreserved from males 2 and 3 and used during 18 inseminations. ${ }^{\mathrm{b}} \mathrm{DS}$, directional solidification freezing method. ${ }^{\mathrm{c}}$ Final volume of insemination dose. ${ }^{\mathrm{d}}$ Kinetic rating of spermatozoa graded subjectively: 0 , no movement; 5 , rapid forward progression. ${ }^{\mathrm{e}} \mathrm{Sperm}$ motility index $=$ progressive motility $\times$ kinetic rating.

and ovulation. The combination of endocrine evaluation with the development of semen collection, storage, and cryopreservation techniques, as well as ovarian ultrasound evaluation, has enabled us to develop the first successful and repeatable Al method in this species.

Previous to this research, no information had been published on the reproductive cycle of Pacific whitesided dolphins. However, methods used in this research were also developed or in some cases evolved simultaneously from research conducted with the killer whale and bottlenose dolphin, the first two cetaceans where the development of Al was successful (Robeck et al. 2004, 2005b). As with killer whales and bottlenose dolphins, training of the Pacific white-sided dolphins for daily urine collection was required before endocrinemonitoring techniques could be applied (Walker et al. 1988, Robeck et al. 1993, 2004).

Unlike killer whales and bottlenose dolphins, male and female Pacific white-sided dolphins exhibit distinct reproductive seasonality. The data of this study are in support of post-mortem research from wild populations, which identified a distinct 3-month pattern of reproductive activity (Harrison et al. 1972, Ferrero et al. 1993). However, females of the present study had the highest incident of both estrus activity and calving during August to October, while data from the wild Northern Pacific ocean population suggest peak reproductive activity occurs from June to August (Ferrero et al. 1993). This 2-month shift in seasonal reproductive activity may reflect the different geographical origin of founder animals in the captive population. Additional evidence in support of a geographical influence on seasonal reproductive patterns is the limited period of semen production by the two males located in Japan (incidentally caught in fisheries off Japan's Northern coast) to
June and early July (S Inoue, unpublished observations), while the USA male's peak seasonality corresponded with the females in this study. Also, the recent successful natural birth of a Pacific white-sided dolphin in Japan (E Katsumata, unpublished observations) has occurred in May. Recent mtDNA evidence suggests that distinct genetically isolated population groups exist even between the relatively close populations of the Sea of Japan and Northern Pacific coastal animals (Hayano et al. 2004). Varying evolutionary pressures based on geographic location have been hypothesized as being responsible for the existence of regional differences in peak reproductive activity across populations of bottlenose dolphins (Urian et al. 1996).

The seasonal changes in semen production were different from any cetacean described to date, with the Pacific white-sided dolphin male demonstrating a true seasonal decrease in serum testosterone concentrations, a corresponding seasonal azoospermia, and an ultrasonographically documented significant decrease in testicular size. Both the bottlenose dolphin and the killer whale exhibit a diffuse seasonality, where females can breed throughout the year and males can exhibit seasonal peaks in $\mathrm{T}$, which can vary within the animal and between years among animals. However, sperm production remains unchanged for both these species (Robeck \& O'Brien 2004, Robeck \& Monfort 2006). The beluga, which has a defined and repeatable reproductive seasonality, undergoes estrus activity from March to June (Robeck et al. 2005a). A male beluga exhibited periods of peak serum $\mathrm{T}$ (October-April) and sperm production (January-June). While the same male displayed a decrease in serum $\mathrm{T}$ and sperm production during $\mathrm{T}$ nadir months of July-September, ejaculates were never azoospermic (O'Brien et al. 2008). The Pacific 


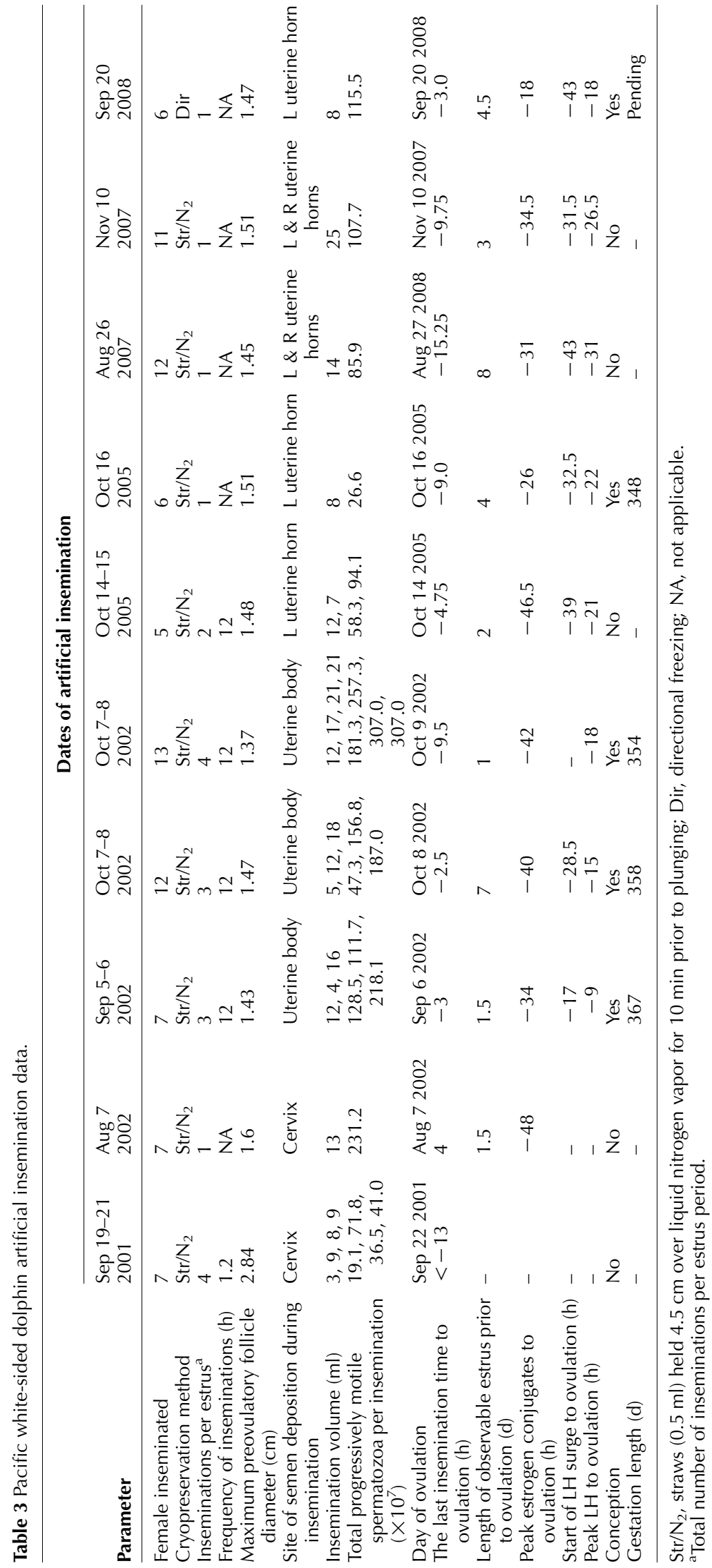


white-sided dolphin in the current study exhibited similar but more pronounced peak sperm production with a lag time after peak $T$ production of 60 days. In contrast, peak testicular diameter had a lag time after peak $\mathrm{T}$ of only 30 days. This evidence supports a spermatogenic cycle of 60 days, similar to other domestic species (Amann \& Schanbacher 1983).

During the study, animals ovulated twice during their season, demonstrating that this species can be seasonally polyestrus. The inter-ovulatory interval of $31 \mathrm{~d}(n=5)$ is similar in length to that for the Indo-Pacific bottlenose dolphin (30 d, Brook et al. 2004) and the Atlantic bottlenose dolphin (33 days, Robeck et al. 2005b; TR Robeck \& JK O'Brien 2008, unpublished observations).

Consistent detection of the start of the preovulatory LH surge required that urine samples were collected for monitoring at a minimum of three times a day. Samples collected every $4 \mathrm{~h}$ were used to define the temporal dynamics of the LH surge, which demonstrated an increase from baseline to peak of $14 \mathrm{~h}$, longer than that which was observed for bottlenose dolphins ( 9 h; Robeck et al. 2005b). However, the length of time from the LH peak to ovulation in the Pacific white-sided dolphin of $17 \mathrm{~h}$ was 29 and $55 \%$ shorter than that observed for bottlenose dolphins (24 h: Robeck et al. 2005b) and killer whales (38 h: Robeck et al. 2004) respectively.

The strategy of inseminating every $12 \mathrm{~h}$ once estrus and/or a POF has been detected and until ovulation is not appropriate for species where semen is of limited supply or unique in value (e.g. sexed semen). To enable efficient use of semen, accurate prediction of ovulation timing is critical. During the initial development of Al for this species, a rapid LH test that could reliably predict ovulation was not available. Thus, we relied on our onsite EC assay to determine peak estrogen production by the POF, and use this point to predict approaching ovulation. As we improved the speed and portability of the LH assay (Steinman et al. 2003, O'Brien \& Robeck 2006), we were able to rely on the more accurate and consistent LH surge to predict ovulation.

Once the LH surge had been characterized (20012005), we were able to use three samples per day at 6 hourly intervals (e.g. 0800, 1400, and 2000 h), with a $12 \mathrm{~h}$ gap during the night. However, if the surge commenced at night during the 12-h-sampling gap, this sampling strategy diminished our ability to accurately predict $\mathrm{LH}$ surge initiation. In order to address this problem, two methods were employed, 1 ) the use of the rapid (20 min) qualitative cLH test kit and 2) multiple urine tests (every $3-4 \mathrm{~h}$ ) after the first positive test. The analysis of multiple urine samples allowed for a semiquantitative indicator of the direction in which the $\mathrm{LH}$ concentration was heading (up or down). When this information was combined with the known interval from LH surge onset to peak LH concentration (14 h), we could estimate the timing of start of the $\mathrm{LH}$ surge, and thus predict the timing of approaching ovulation.
The use of altrenogest in marine mammals for contraception or as a synchronization agent has been well documented in killer whales, bottlenose dolphins, and beluga (Young \& Huff 1996, Robeck et al. 2001, 2004, 2005b, Steinman et al. 2007). However, unlike killer whales and bottlenose dolphins, at the time of study, the Pacific white-sided dolphin was the first seasonally estrus cetacean where altrenogest had been used. As a result, when to administer the hormone (before or during the short breeding season) for optimum effectiveness was unknown.

In the horse, altrenogest is most effective at synchronizing estrus during the breeding season with little or no effect during seasonal anestrus (Webel \& Squires 1982, Squires et al. 1983). Since the Pacific white-sided dolphins exhibited seasonal estrus activity from July to October, no attempts were made to synchronize them outside of this period. Even with this targeted administration plan, the overall success of this administration was only $16 \%$. The reason for this poor response when compared with bottlenose dolphins, which typically have a 50\% response to regumate (Robeck et al. 2005b), is unknown and may simply be an effect of the Pacific white-sided dolphin's tight reproductive seasonality.

The use of altrenogest as a synchronization agent in the Pacific white-sided dolphins results in a long delay from hormone withdrawal to ovulation of $20 \mathrm{~d}$. This response is similar to the bottlenose dolphin (Robeck et al. 2005b). Both of these species have similar follicular dynamics, in that they do not have large numbers of recruitable follicles present on the ovary at any given time (i.e. follicle > $4.0-4.5 \mathrm{~mm}$ for bovine; Guilbault et al. 1991, Ginther et al. 1998). Thus, they do not have continuous waves of follicles from which a portion is always receptive for recruitment post-progesterone administration. Since only small, non-growing follicles $(<0.4 \mathrm{~mm}$ in diameter) are available for recruitment, the lack of continuous follicular waves in dolphins may account for the protracted response from progestogen withdrawal to ovulation when compared to the domestic pig (7-9 days; Kraeling et al. 1981, Pursel et al. 1981) and the horse (9 days for the normally cycling horse; Squires et al. 1983, Daels et al. 1996). Understanding the mechanism for the initiation of this recruitment may provide the solution for developing a more effective estrus induction and synchronization method.

Evaluation of ovaries using transabdominal ultrasonography has been previously reported in other cetacean species including the bottlenose dolphin (Robeck et al. 1998, 2005b, Brook 2001), Indo-Pacific humpback dolphin (Brook et al. 2004), killer whales (Robeck et al. 2004), and the beluga (Robeck et al. 2007). The circumferential daily growth rate of $0.41 \mathrm{~cm}$ and the maximum POF diameter of $1.5 \mathrm{~cm}$ in the Pacific white-sided dolphin were different from the bottlenose dolphin of 0.47 and $2.1 \mathrm{~cm}$ respectively. Since the follicular phase length is similar for both species, 
the slightly faster growth rate for the bottlenose dolphin is reflective of a larger POF at ovulation. In addition, dominant follicle selection appears to occur around $0.8 \mathrm{~cm}$ in the Pacific white-sided dolphin as opposed to $\sim 1 \mathrm{~cm}$ in the bottlenose dolphin. Similar to bottlenose dolphins (Robeck et al. 2005b), POF size in the Pacific white-sided dolphins did not correlate to urinary estrogen concentrations or animal body mass.

Ovulation occurred $100 \%$ of the time on the left ovary of the Pacific white-sided dolphin, this is an even greater degree of unilateralism than what was found in the bottlenose dolphin where ovulation occurred $82 \%$ on the left ovary (Ohsumi 1964, Robeck et al. 2005b). The reason for this unilateralism in ovulation is unknown. Also, as with bottlenose dolphins and Indo-Pacific dolphins (Brook et al. 2004), secondary follicles were observed; however, unlike bottlenose dolphins, secondary follicles did not regress but were present at ovulation in $31 \%$ of the observed ovulations. Cystic follicles developed in two different females during natural cycles. Two females had what appeared to be cystic ovaries throughout the study. One animal had a single large ovarian cyst that never changed in size and the other had multiple small cysts that remained on the ovary throughout the year. Abnormal ovarian cysts have been observed in bottlenose dolphins and in a killer whale. The origin and/or significance of these cysts are unknown, but all animals where this has been observed (including the animals in this study) were able to conceive.

The raw ejaculate characteristics presented herein are the first published data from this species, and during their season they are comparable in quality and concentration to those obtained from the bottlenose dolphin (Schroeder \& Keller 1989, Robeck \& O'Brien 2004). Owing to the limited number and overrepresentation of the male available for semen collection in the US, all the inseminations were completed using frozen-thawed semen imported from two males located in Japan. The minimum effective dose of 260 million PM spermatozoa required for conception in the Pacific white-sided dolphin is similar to that of cryopreserved bottlenose dolphin semen (270 million PM spermatozoa; Robeck et al. 2005b), but is considerably more than that achieved with sex-sorted, cryopreserved bottlenose dolphin spermatozoa (150 million PM spermatozoa; O'Brien \& Robeck 2006). This suggests that future insemination efforts with the Pacific white-sided dolphin may require fewer PM spermatozoa for success.

The straw method for cryopreserving semen yielded similar results between the two males evaluated. Since $\sim 50 \%$ of initial motility was maintained post-thawing, it appears that this method is adequate for gamete storage and use with Al. While not directly comparable, the directional freezing method enabled $94 \%$ of initial motility to be maintained post-thaw, thereby illustrating the potential vast improvement this technology can offer over the conventional straw method. These findings are in agreement with recent cryopreservation studies using sexed bottlenose dolphin spermatozoa $\left(\mathrm{O}^{\prime}\right.$ Brien \& Robeck 2006) and non-sexed beluga semen (O'Brien \& Robeck 2007). Clearly, future-controlled experiments objectively evaluating the potential of directional freezing technology in the Pacific white-sided dolphin are warranted.

The mean gestation length of 356 days and range from 348 to $367 d$ is the first description of both the normal length and the potential range of gestation in this species. The length is slightly shorter than bottlenose dolphins that have a mean of $377 \mathrm{~d}$ and range from 357 to $399 \mathrm{~d}$ (Robeck et al. 2005b; JK O'Brien \& TR Robeck unpublished observations).

The combination of years of research on basic endocrinology, semen collection, and cryopreservation has allowed for the first successful application of $\mathrm{Al}$ in the Pacific white-sided dolphin. Owing to the small North American population size, the ability to utilize and improve these techniques will largely influence whether or not this species remains in captivity. With that in mind, future efforts with the Pacific white-sided dolphin will be focused on the development of methodologies for sexselecting spermatozoa for use with the Al techniques described herein. Sex selection will allow for a faster increase in the female population or, if necessary, the production of a genetically elite male by inseminating the least represented female with $\mathrm{Y}$ chromosome-bearing spermatozoa from an unrepresented male $\left(\mathrm{O}^{\prime}\right.$ Brien et al. $2002,2009)$. While this species is not endangered in the wild, the degree of genetic and reproductive management required to maintain the diversity of this small ex situ population provides an ideal model for the restoration of any cetacean species that may become endangered in the future.

\section{Materials and Methods}

\section{Animals}

Twelve female and three male Pacific white-sided dolphins (L. obliquidens) located at three facilities were used for various combinations of endocrine monitoring, semen collection, and/or insemination trials (Table 1). During the collection of seasonality data (progesterone and conception data), females 1-8 had constant access to a male for breeding purposes. These data were collected from females 1-8 located at SeaWorld of Texas (SWT; San Antonio, TX 78251, USA) from 1980 to 2001 prior to the initiation of the urine collection for cycle monitoring. Once the Al trials began, the male was separated from candidate females (SWT) for a minimum of 1 month prior to the procedures. Male 1 and females 1-8 located at SWT were housed in an $\sim 7445 \mathrm{~m}^{3}$ manufactured saltwater enclosure (temperature: controlled from 17 to $20^{\circ} \mathrm{C}$ ). Females 8-12 were housed in a $15141 \mathrm{~m}^{3}$ indoor manufactured saltwater habitat (water temperature from 17 to $20^{\circ} \mathrm{C}$ ) at the John G Shedd Aquarium (Chicago Zoological Society, Chicago, IL 60605, USA). 
Males 2 and 3 were housed with a mixed age group of males in a $1200 \mathrm{~m}^{3}$ outdoor facility containing natural saltwater (Ambient water temperature: $17-28^{\circ} \mathrm{C}$ ) located at Kamogawa Sea World (Kamogawa, Chiba, Japan).

Animals located in the US were fed a diet of frozen-thawed whole fish (herring, Clupea harengus; capelin, Mallotus villosus; and Columbia River smelt, Thaleichthys pacificus). The male in Japan was fed chub mackerel (Scomber japonicus), Arabesque greenling (Pleurogrammus azonus), and capelin (M. villosus). All animals were fed at approximately $4-5 \%$ of their body weight per day.

\section{Ethics of experimentation}

All samples were collected using routine husbandry training and were obtained on unrestrained animals. All procedures described within were reviewed and approved by the SeaWorld Incorporated Institutional Animal Care and Use Committee, and were performed in accordance with the Animal Welfare Act for the care of Marine Mammals.

\section{Female reproductive seasonality}

Serum samples $(n=511)$ for $\mathrm{P}$ concentrations were collected for 8-23 years from females $1-7$ on a bimonthly to monthly schedule (Table 1). For each individual female, $\mathrm{P}$ concentrations that exceeded $3 \mathrm{ng} / \mathrm{ml}$ and were at least 2.0 times the mean non-pregnant $\mathrm{P}$ concentration for that particular individual were considered presumptive evidence of luteal activity (Robeck et al. 2005a). When a sample below this threshold was serially adjacent to a sample above the threshold, the beginning or end of a luteal phase was defined as median point between these two samples. The value with the highest concentration during a period of luteal activity was considered the peak. To determine the frequency during each month that reproductive activity occurred, the total number of a peak luteal phase that occurred during each month was combined across all sample years to develop a composite 12-month period.

\section{Male reproductive seasonality}

Testosterone concentrations were measured in 52 serum samples collected bimonthly for 1 year and during routine health exams over 7 years from male 1. Ultrasound evaluations ( $n=17$; Aloka 900 machine with a $3.5 \mathrm{MHz}$ wide footprint convex linear transducer (Corimetrics Medical, Charlotte, NC, USA)) of right and left testicles were conducted monthly (OctMar) or biweekly (May-Sept) for 1.5 years to determine whether seasonal changes occur in maximum testicular diameter and stromal echogenicity. The echogenic tissue patterns were characterized by comparing the echogenicity of the testes during each examination to the surrounding musculature (HLM) as described for bottlenose dolphins (Brook et al. 2000). Ejaculates $(n=290)$ were collected from male 1 (see Methods below) throughout the year for 3 years to determine seasonal production of spermatozoa. Ejaculate sperm concentration and total volume were determined using standardized techniques (Robeck \& O'Brien 2004).

\section{Urinary endocrine monitoring}

Urine samples were collected from unrestrained female Pacific white-sided dolphins as previously described for bottlenose dolphins (Robeck et al. 2005b). Briefly, the animals were trained to lay on their back in the water with their flukes and peduncle resting in the lap of a trainer who was sitting on the edge of the pool. A second trainer would apply firm, steady pressure on the abdomen directly over the urinary bladder. The animals would urinate in response to the pressure and eventually became conditioned to urinate with only a slight touch in the same location. The urine was aspirated from the genital slit with a $10 \mathrm{ml}$ syringe. All urine samples collected $(n=3388)$ were used for monitoring of estrous activity, evaluating synchronization attempts, or for Al trials (Table 1). Samples were stored in duplicate at $-70^{\circ} \mathrm{C}$ until analysis. Non-extracted urine samples were analyzed by enzyme immunoassay (EIA) for total immunoreactive levels of UP, EC, and $\mathrm{LH}$. Urine samples were collected daily until 10 days postsynchronization, then from 3 (minimum) to 5 times a day during the estimated periovulatory period.

Determination of total estrous cycle length was based on either the interval between the beginning of successive $\mathrm{LH}$ peaks or successive EC peaks. For the study, LH and EC peaks were defined as the maximum concentration for the respective hormones during the estrous period (Robeck et al. 2004, $2005 b$ ). Baseline concentrations (BC) were determined for all hormones in each individual animal by standard methods. Deviations above or a return to baseline for a minimum of two consecutive samples were used to define the beginning or the end respectively of a physiologically significant change in a particular hormone. Using this method, the following intraestrous cycle endocrine components were determined: length of the luteal phase (UP concentrations $>$ than BC for 2 consecutive days), follicular phase (EC concentrations $>$ BC for 2 consecutive days), start of follicular phase to peak EC, and peak EC to peak $\mathrm{LH}$ were determined. The preovulatory rise in EC concentrations was subjectively defined as values $>2$ s.D.s. above baseline until the $\mathrm{LH}$ peak. The time from the beginning of the $\mathrm{LH}$ surge to peak $\mathrm{LH}$ and the total length of the LH surge were determined in animals with a minimum thrice daily sample collection. The beginning of the surge was defined as any value $>2$ s.D. above baseline for that animal that was followed by the LH peak. If the LH surge began or ended between two sample periods, we subjectively assigned the beginning of the surge as occurring midway between the two samples. A 'normal' estrous cycle was determined by combining the mean values from all Pacific white-sided dolphins for all of the above-mentioned intervals.

Endocrine data were compared to the ultrasonographically estimated ovulation point (the midpoint between exams where the follicle is present in one and disappears in the next) to define the interval between the EC and LH peak and ovulation.

\section{Creatinine assay}

Urine samples were analyzed for $\mathrm{Cr}$ to account for varying concentrations of urine as previously described (Taussky 1954). Concentrations of urinary hormones and metabolites were expressed as mass of hormone per $\mathrm{mg} \mathrm{Cr}$ excreted. 


\section{EIA for estrogen conjugates}

Urinary EC were measured by single antibody, direct EIA as previously described (Robeck et al. 2004, 2005b). Briefly, neat urine samples $(0.025-0.0025 \mathrm{ml})$ and standards (range $200-0.79 \mathrm{pg} /$ well, Sigma-Aldrich) were added to a microtiter plate coated with E1G antisera, and an enzyme conjugate added to all wells. After incubation, $0.1 \mathrm{ml}$ of substrate, tetramethylbenzidine in phosphate citrate buffer (Sigma-Aldrich) was added to all wells and incubated at room temperature for $30 \mathrm{~min}$. Finally, $0.05 \mathrm{ml}$ of $0.6 \mathrm{M}$ $\mathrm{H}_{2} \mathrm{SO}_{4}$ was added. Intra-assay variation was $<10 \%$ and inter-assay variation was $11.1 \%$ and $11.7 \%$ at 30 and $70 \%$ binding $(n=163)$. Serial dilutions of the Pacific white-sided dolphin urine yielded displacement curves that were similar to the standard curve $\left(R^{2}=0.99\right)$. The mean recovery of estrone glucuronide added to a pool of the Pacific whitesided dolphin urine was $96.7 \pm 30.2 \% \quad(y=0.94 x+0.585$, $\left.R^{2}=0.99\right)$. Immunoassay of fractions separated by reversephase HPLC analysis revealed one major immunoreactive peak (fractions $17-23,21 \%$ of total) that co-eluted with estrone-3-sulfate.

\section{LH enzyme immunoassay}

A rapid urinary $\mathrm{LH}$ assay was used which allowed $\mathrm{LH}$ concentration determination within $2.5 \mathrm{~h}$ using a single antibody, direct EIA (O'Brien \& Robeck 2006) previously modified from the double antibody EIA developed by Graham et al. (2002). Intra-assay variation was $<10 \%$ and inter-assay variation was 12.3 and $11.1 \%$ at 30 and $60 \%$ binding $(n=124)$. Serial dilutions of the Pacific white-sided dolphin urine yielded displacement curves that were similar to the standard curve $\left(R^{2}=0.99\right)$. The mean recovery of $\mathrm{LH}$ added to a pool of the Pacific white-sided dolphin urine was $42.8 \pm 15.7 \%$ $\left(y=0.62 x-0.74, R^{2}=0.99\right)$.

In addition to the qLH assay, the rapid semi-quantitative cLH kit (Witness Synbiotics Corp., Kansas City, MO, USA) was validated by comparing results to the $\mathrm{qLH}$. The kits were validated by comparing colorimetric changes in the sample line (when compared to the sample control line) to urinary concentrations as described by the qLH assay and to the control. The sample lines were described as: slightly visible, slightly less than, equal to, slightly greater than, or maximal when compared with the control line. Subjective $\mathrm{Cr}$ values were assigned to each sample based on degree of yellow color (low, medium, or high).

\section{Assay for urinary progestins}

UP were measured by single antibody, direct EIA as previously described (Graham et al. 2001, Robeck et al. 2005b). Intraassay variation was $<10 \%$ and inter-assay variations were 12.3 and $8.7 \%$ at 30 and $70 \%$ binding $(n=173)$. Serial dilutions of the Pacific white-sided dolphin urine yielded displacement curves that were similar to the standard curve $\left(R^{2}=0.99\right)$. The mean recovery of progesterone added to a pool of the Pacific white-sided dolphin urine was $91.6 \pm 22.8 \%$ $\left(y=0.99 x-1.57, R^{2}=0.99\right)$. Immunoassay of fractions separated by reverse-phase HPLC analysis revealed an immunoreactive peak at fractions $67-71$ that co-eluted with progesterone and two peaks at $73-76$ and $77-80$ that were unidentified.

\section{Synchronization of ovulation}

To evaluate the effects of an orally administered exogenous progestin, a synchronization tool for use with $\mathrm{Al}$, animals were placed on $0.044 \mathrm{mg} / \mathrm{kg}$ p.o. of altrenogest (Regu-Mate, Intervet Inc., Millsboro, DE, USA) once a day for treatment periods lasting from 20 to $30 \mathrm{~d}$. From 2001 to 2008, a total of 76 treatments were administered to ten female Pacific white-sided dolphins. The drug was administered by injecting directly into the coelomic cavity of a herring just prior to feeding. Immunoreactive UP, EC, and LH were determined from urine samples collected daily during, and at least twice daily after, cessation of altrenogest treatment.

\section{Ovarian ultrasonography}

Transabdominal ultrasonography was used to detail follicular activity during natural cycles, following altrenogest-induced cycles and to confirm pregnancy as previously described for bottlenose dolphins (Brook 2001, Robeck et al. 2005b). Ultrasonographic examinations were performed using either an Aloka 900 machine (SWT: Corimetrics Medical), GE Logibook Book (SWT: GE LogiqGE Medical Systems, Milwaukee, WI, USA), or a SonoSite 180 Plus (Shedd: SonoSite, Inc., Bothell, WA, USA) all with a $3.5 \mathrm{MHz}$ transducer (wide footprint convex linear probe). Females were examined once on day 0 and $10 \mathrm{~d}$ post-altrenogest, then daily to thrice daily from day 11 to ovulation. In addition, any female exhibiting a follicle of $0.8 \mathrm{~mm}$ or greater in diameter was examined daily until the fate of follicular development could be determined. Once a potential POF was observed, the ovaries were visualized a minimum of three times daily with ultrasound. Follicular diameter and circumference and the time of ovulation were determined as previously described (Robeck et al. 2005b).

\section{Semen collection and processing}

Ejaculates were collected from male $2(n=10)$ and male 3 $(n=5)$ for cryopreservation and use during the Al trials (Table 2). Males were trained for unrestrained ejaculation as previously described (Keller 1986, Robeck \& O'Brien 2004). Briefly, the animals received various tactile stimulations to elicit voluntary extrusion of the penis from the genital groove. After an erection was obtained, animals were conditioned to ejaculate by stimulation often directed towards the perineal area. Once the animals subjectively appeared in a preejaculatory state, the penis was grasped with a gloved hand (Nitrisoft, Nitrile latex free examination glove; Sintex, Houston, TX, USA) and the ejaculate directed into a $24 \mathrm{oz}$ WHIRL-PAK (NASCO, Fort Atkinson, WI, USA).

Ejaculate concentration, volume, sperm motility, and viability (plasma membrane integrity) were determined using standardized techniques (Robeck \& O'Brien 2004, 
Robeck et al. 2005b). The percentages of motile sperm were subjectively determined to the nearest $5 \%$ by analyzing four to five fields of diluted spermatozoa $\left(35^{\circ} \mathrm{C}, 1: 25\right.$, spermatozoa:egg yolk citrate cryodiluent (EYC); $2.9 \%$ Na citrate; $20 \%$ egg yolk (v/v); and gentamycin $50 \mathrm{ug} / \mathrm{ml})$ using bright-field optics ( $\times 400$, Olympus, Tokyo, Japan). TM, PM, and kinetic rating (KR, $0-5$ scale; 0, no forward movement; 5, rapid forward progressive movement) were subjectively determined. A sperm motility index (SMI:PM $\times K R$ ) was used for comparisons of sperm quality between fresh and frozen-thawed spermatozoa (Robeck \& O’Brien 2004).

For assessment of viability, $10 \mu$ l of semen was mixed with $40 \mu \mathrm{l}$ of a live-dead exclusion stain (eosin-nigrosin; IMV International Corp., Maple Grove, MN, USA) for 30 s. For each ejaculate, an air-dried smear was used to evaluate 200 spermatozoa using bright-field optics $(\times 1000)$. Spermatozoa were then placed into one of the two groups based on stain uptake by the sperm head: live (no stain uptake) and dead (partial or complete stain uptake).

\section{Processing of semen for frozen storage}

Semen was processed for cryopreservation over 5 years, and as advancements in cetacean sperm cryopreservation methods evolved they were applied to the species herein. Thus, two cryopreservation methods were applied to semen used in the Al trials.

\section{Method 1}

Ejaculates (male 2, $n=10$; male 3, $n=3$ ) were diluted 1:1 (v/v) with EYC cryodiluent and cooled from 21 to $5{ }^{\circ} \mathrm{C}$ over $1 \mathrm{~h}$ $\left(-0.27^{\circ} \mathrm{C} / \mathrm{min}\right)$. At $5{ }^{\circ} \mathrm{C}$, the sample was further diluted $(1: 1)$ with glycerolated EYC ( $6 \% \mathrm{v} / \mathrm{v}$ final glycerol concentration) slowly over $5 \mathrm{~min}$. The sperm suspension was transferred to $0.5 \mathrm{ml}$ straws (IMV International), sealed, and frozen in liquid nitrogen vapor at a distance of $4.5 \mathrm{~cm}$ above the vapor $\left(-12^{\circ} \mathrm{C} / \mathrm{min}\right)$ for $10 \mathrm{~min}$ then plunged into liquid nitrogen.

The straws were thawed by plunging directly into a $35{ }^{\circ} \mathrm{C}$ water bath and shaken vigorously for $1 \mathrm{~min}\left(8.3^{\circ} \mathrm{C} / \mathrm{s}\right)$. Straws were combined and $100 \mu \mathrm{l}$ aliquot of the combined sample were removed and diluted (1:1 over 5 min) with EYC (warmed to $35^{\circ} \mathrm{C}$ ), and used for post-thaw analysis as previously described for raw ejaculates. The remainder of the sample was stored at $21^{\circ} \mathrm{C}$ until the insemination.

\section{Method 2}

Ejaculates (male 2, $n=2$ ) were diluted 1:1 (v/v) with Beltsville extender (BF5F; Pursel \& Johnson 1975). BF5F was modified to contain $52.3 \mathrm{mM}$ TES, $16.5 \mathrm{mM}$ Tris, $105.4 \mathrm{mM}$ fructose, $105.4 \mathrm{mM}$ glucose, $20 \% \mathrm{v} / \mathrm{v}$ egg yolk, and gentamycin $50 \mu \mathrm{g} /$ $\mathrm{ml}(330 \pm 5 \mathrm{mOsm} / \mathrm{kg}$ and $\mathrm{pH} 7.0 \pm 0.1)$. The sperm solution was cooled from 21 to $5{ }^{\circ} \mathrm{C}$ over $1.5 \mathrm{~h}\left(\approx-0.2{ }^{\circ} \mathrm{C} / \mathrm{min}\right)$. At $5{ }^{\circ} \mathrm{C}$, the sample was further diluted $(1: 1)$ with glycerolated BF5F (5\% v/v final glycerol concentration) in a stepwise manner over $30 \mathrm{~min}$. After equilibration for $1 \mathrm{~h}$, sperm suspensions were transferred to $9 \mathrm{ml}$ hollow tubes (IMT
International Ltd, Chester, UK) for cryopreservation using a directional solidification ('directional freezing') machine (MTG-516, IMT). The hollow tube was moved through the first block $\left(5^{\circ} \mathrm{C}\right)$ for $45 \mathrm{~s}$ at a constant velocity $(3 \mathrm{~mm} / \mathrm{s})$ before reaching a distance of $2 \mathrm{~mm}$ into the opening of a second block $\left(-50^{\circ} \mathrm{C}\right)$ and held for $30 \mathrm{~s}$ for initiation of seeding (rapid induction of ice nucleation from the seeding point throughout the length of the glass tube). The tube was then moved at $1 \mathrm{~mm} / \mathrm{s}$ across the second block for 5 min before entering the collection chamber $\left(-100\right.$ to $\left.-110{ }^{\circ} \mathrm{C}\right)$, followed by immediate transfer to liquid nitrogen. Hollow tubes were thawed in air for $90 \mathrm{~s}$, then transferred to a $35^{\circ} \mathrm{C}$ water bath equipped with modifications to enable uniform sample thawing (Harmony CryoCare Activator IMT International). One $9 \mathrm{ml}$ tube was required for each insemination. A $100 \mu$ laliquot of the sample was removed, and diluted (1:1 over $5 \mathrm{~min}$ ) with BF5F (warmed to $35{ }^{\circ} \mathrm{C}$ ) and used for post-thaw analysis as previously described for raw ejaculates. The remaining sample was stored at $21^{\circ} \mathrm{C}$ until the insemination.

\section{Artificial insemination}

The first five inseminations (females 7, 12, and 13) from 2001 to 2002 were based on the presence of a presumptive POF and the detection of peak urinary EC. For these inseminations, urinary estrogen levels were determined twice daily when a female possessed a consistently growing follicle that had reached a diameter of $1.2 \mathrm{~cm}$. Once peak EC concentrations occurred (estimated to have occurred by a decrease in EC concentrations in the successive sample) the female was inseminated $\sim 12 \mathrm{~h}$ after the peak, continuing every $12 \mathrm{~h}$ until ovulation. Inseminations 6 and 7 (2005; females 5 and 6) and insemination 10 (2008; female 6) were timed to occur $24 \mathrm{~h}$ after the start of the urinary pre-ovulatory LH surge and every $12 \mathrm{~h}$ until ovulation. During 2007, the insemination method for females 11 and 13 was modified to include methodology under parallel development in beluga (Robeck et al. 2007, Steinman et al. 2007, O'Brien et al. 2008) and bottlenose dolphins (TR Robeck \& JK O'Brien 2007, unpublished observations). Females with apparent POFs $(>1.4 \mathrm{~cm}$ in diameter) and elevated urinary estrogens for greater than 10 days were administered three i.v. injections of a GnRH analog (Cystorelin, Merial, Duluth, GA, USA; $250 \mu \mathrm{g}$ per injection, $\mathrm{q} .1 \mathrm{~h}$ ) to control the timing of ovulation. The insemination took place $22 \mathrm{~h}$ after the first GnRH injection.

All females were pre-medicated with diazepam (Abbott Lab; $0.1-0.2 \mathrm{mg} / \mathrm{kg}$ ) $1-2 \mathrm{~h}$ prior to each procedure. The females were removed from the water and placed in lateral recumbency on 10.2-cm-thick closed cell foam pads. All females were kept wet during the procedure and vital signs were monitored throughout. Inseminations were performed using a flexible endoscope (either a $8.5 \mathrm{~mm}$ external diameter, $150 \mathrm{~cm}$ long; Karl Storz Veterinary Endoscopy America, Santa Barbara, CA, USA, or a $6.0 \mathrm{~mm}$ external diameter, $120 \mathrm{~cm}$ long Olympus America, Melville, NY, USA) equipped with a catheter in the working channel $(2.2 \mathrm{~mm}$ external diameter $(5 \mathrm{fr}), 190 \mathrm{~cm}$ long; SurgiVet, Waukesha, WI, USA). For the procedures, the endoscope was advanced into the cranial vagina. The vagina was insufflated with air to visualize the cervical opening 
(Robeck et al. 2005b). The semen was deposited in the cervix (inseminations 1 and 2), uterine body (inseminations 3-5), or the uterine horn ipsilateral to the POF (inseminations 6-10).

\section{Statistical analyses}

Hormone and sperm quality data were analyzed by ANOVA and means compared using Newman-Keuls' multiple comparisons, Mann-Whitney $U$ test for non-parametric data, Kruskal-Wallis ANOVA on ranks and Dunn's multiple comparisons (SigmaStat, Version 2.0. SPSS Inc., San Rafael, CA, USA). Repeated-measures ANOVA on ranks and Holm-Sidak multiple comparisons were used to compare monthly changes in hormone or testes size for seasonality data. Data were considered significant if $P<0.05$ and were presented as mean \pm s.D.

\section{Declaration of interest}

The authors declare that there is no conflict of interest that would prejudice the impartiality of this research.

\section{Funding}

This project was supported by SeaWorld Corp. and John G Shedd Aquarium.

\section{Acknowledgements}

The veterinary, animal laboratory, animal care and animal training staff at SeaWorld Texas, Kamogawa Sea World, and the John G Shedd Aquarium. Special mention goes to Drs Jeff Boehm (JGS Aquarium) and Steve Monfort (CRC, National Zoological Park) for their support of this project and Dr Leigh Clayton (JGS Aquarium) for performing ultrasound examinations. Doug Acton (SWT) and Satoshi Inoue (KSW) are thanked for all of their efforts in conditioning the animals for semen sample collection. We thank Dr Sam Dover and Karl Strotz Veterinary Endoscopy for lending us the endoscopic equipment utilized in the 2002 inseminations. Dr Gisele Montano and Michelle Morrisseau (SWBGRRC) are thanked for their help with the Als. We thank Brad Andrews (SeaWorld Inc) for his continued support of this project. Finally, we thank and recognize the late Dr Teruo Tobayama (Kamogawa Sea World) for his support of and in interest in this work. This research was conducted on the NMFS permit numbers 782-1694 and 1161691. This article is a SeaWorld Technical contribution Number 2008-02-T.

\section{References}

Amann RP \& Schanbacher BD 1983 Physiology of male reproduction. Journal of Animal Science 57 380-403.

Brook FM 2001 Sonographic imaging of the reproductive tract of the female bottlenose dolphin, Tursiops truncatus aduncas. Reproduction 121 419-428.

Brook FM, Kinoshita R, Brown B \& Metreweli C 2000 Ultrasonographic imaging of the testis and epididymis of the bottlenose dolphin, Tursiops truncatus aduncas. Journal of Reproduction and Fertility 119 233-240.
Brook FM, Lim EHT, Chua FHC \& Mackay B 2004 Assessment of the reproductive cycle of the Indo-Pacific humpback dolphin, Sousa chinensis, using ultrasonography. Aquatic Mammals 30 137-148.

Daels PF, McCue PM, DeMoraes MJ \& Hughes JP 1996 Persistence of the luteal phase following ovulation during altrenogest treatment in mares. Theriogenology 46 799-811.

Ferrero RC \& Walker WA 1996 Age, growth, and reproductive patterns of the Pacific white-sided dolphin (Lagenorhynchus obliquidens) taken in high seas drift nets in the central North Pacific ocean. Canadian Journal of Zoology 74 1673-1687.

Ferrero RC, Walker WA \& Gosho M 1993 Preliminary analysis of northern right whale dolphin (Lissodelphis borealis) and Pacific white-sided dolphin (Lagenorhynchus obliquedens) age and reproductive parameters from the Japanese squid driftnet fishery, June-November 1990. International North Pacific Fisheries Commission Bulletin 53 297-312.

Ginther OJ, Bergfelt DR, Kulick LJ \& Kot K 1998 Pulsatility of systemic FSH and $\mathrm{LH}$ concentrations during follicular-wave development in cattle. Theriogenology 50 507-519.

Graham L, Schwarzenberger F, Möstl E, Galama W \& Savage A 2001 $A$ versatile enzyme immunoassay for the determination of progestogens in feces and serum. Zoo Biology 20 227-236.

Graham LG, Boling J, Miller G, Pratt-Hawkes N \& Joseph S 2002 Enzymeimmunoassay for the measurement of luteinizing hormone in the serum of African elephants (Loxodonta africana). Zoo Biology 21 403-408.

Guilbault LA, Lussier JG, Grasso F, Matton P \& Rouillier P 1991 Follicular dynamics and superovulation in cattle. Canadian Veterinary Journal $\mathbf{3 2}$ 91-93.

Hammond PS, Bearzi G, Bjørge A, Forney K, Karczmarski L, Kasuya T, Perrin WF, Scott MD, Wang JY, Wells RS et al. 2008 Lagenorhynchus obliquidens. In IUCN 2008. 2008 IUCN Red List of Threatened Species. www.iucnredlist.org. Downloaded on 20 November 2008.

Harrison RJ \& McBrearty DA 1977 Ovarian appearances in captive delphinids. Aquatic Mammals 5 57-66.

Harrison RJ, Brownell RL \& Boyce RC 1972 Reproduction and gonadal appearance in some odontocetes. In Functional Anatomy of Marine Mammals, vol 1, pp 361-429. Ed RJ Harrison. New York: Academic Press.

Hayano A, Yoshioka M, Tanaka M \& Amano M 2004 Population differentiation in the Pacific white-sided dolphin Lagenorhynchus obliquidens inferred from mitochondrial DNA and microsatellite analysis. Zoological Science 21 989-999.

Keller KV 1986 Training of the bottlenose dolphins (Tursiops truncates) for artificial insemination. International Association for Aquatic Animal Medicine 14 22-24.

Kraeling RR, Dziuk PJ, Pursel VG, Rampacek GB \& Webel SK 1981 Synchronization of estrus in swine with ally trenbolone (RU-2267). Journal of Animal Science 52 831-835.

O'Brien JK \& Robeck TR 2006 Development of sperm sexing and associated assisted reproductive technology for sex pre-selection of captive bottlenose dolphins (Tursiops truncatus). Reproduction, Fertility, and Development 18 319-329.

O'Brien JK \& Robeck TR 2007 Semen collection, characterization and preservation in a beluga (Delphinapterus leucas). In 1st International Workshop on Beluga Whale Research, Husbandry and Management in Wild and Captive Environments, Valencia, Spain. pp 8-9.

O'Brien JK, Crichton EG, Evans KM, Schenk JL, Stojanov T, Evans G, Maxwell WMC \& Loskutoff NM 2002 Sex ratio modification using sperm sorting and assisted reproductive technology - a population management strategy. In 2nd International Symposium on Assisted Reproduction Technologies (ART) Conservation Genetic Management Wildlife, Omaha, Nebraska. pp 224-231.

O'Brien JK, Steinman KJ, Schmitt T \& Robeck TR 2008 Semen collection, characterization and artificial insemination in the beluga (Delphinapterus leucas) using liquid-stored spermatozoa. Reproduction, Fertility, and Development 20 770-783.

O'Brien JK, Steinman KJ \& Robeck TR 2009 Application of sperm sorting and associated reproductive technology for wildlife management and conservation. Theriogenology 71 98-107.

Ohsumi S 1964 Comparison of maturity and accumulation rate of corpora albacantia between the left and right ovaries in cetacean. Scientific Reports of the Whales Research Institute 18 123-149. 
Pursel VG \& Johnson LA 1975 Freezing of boar spermatozoa: fertilizing capacity with concentrated semen and a new thawing procedure. Journal of Animal Science 40 99-102.

Pursel VG, Elliott DO, Newman CW \& Staigmiller RB 1981 Synchronization of estrus in gilts with allyl trenbolone: fecundity after natural service and insemination with frozen semen. Journal of Animal Science $\mathbf{5 2}$ 130-133.

Robeck TR \& Monfort SL 2006 Characterization of male killer whale (Orcinus orca) sexual maturation and reproductive seasonality. Theriogenology 66 242-250.

Robeck TR \& O'Brien JK 2004 Effect of cryopreservation methods and precryopreservation storage on bottlenose dolphin (Tursiops truncatus) spermatozoa. Biology of Reproduction 70 1340-1348.

Robeck TR, Schneyer AL, McBain JF, Dalton LM, Walsh MT, Czekala NM \& Kraemer DC 1993 Analysis of urinary immunoreactive steroid metabolites and gonadotropins for characterization of the estrous cycle, breeding period and seasonal estrous activity of captive killer whales (Orcinus orca). Zoo Biology 12 173-187.

Robeck TR, Atkinson S \& Brook FM 2001 Reproduction. In CRC Handbook in Marine Mammal Medicine, 2 edn, ch 11, pp 193-236. Eds L Dierauf \& F Gulland. Boca Raton: CRC Press.

Robeck TR, Steinman KJ, Gearhart S, Reidarson TR, McBain JF \& Monfort SL 2004 Reproductive physiology and development of artificial insemination technology in killer whales (Orcinus orca). Biology of Reproduction 71 650-660.

Robeck TR, Monfort SL, Calle PP, Dunn JL, Jensen E, Boehm JR, Young S \& Clark ST 2005a Reproduction, growth and development in captive beluga (Delphinapterus leucas). Zoo Biology 24 29-49.

Robeck TR, Steinman KJ, Yoshioka M, Jensen E, O'Brien JK, Katsumata E, Gili C, McBain JF, Sweeney J \& Monfort SL 2005b Estrous cycle characterization and artificial insemination using frozen-thawed spermatozoa in the bottlenose dolphin (Tursiops truncatus). Reproduction 129 659-674.

Robeck TR, Steinman KJ \& O'Brien JK 2007 Understanding reproductive physiology and development of assisted reproductive technology (ART) in beluga, Delphinapterus leucas: contributions of captive and wild research. In 1st International Workshop on Beluga Whale Research, Husbandry and Management in Wild and Captive Environments, Valencia, Spain. pp 7-8.

Schroeder JP \& Keller KV 1989 Seasonality of serum testosterone levels and sperm density in Tursiops truncatus. Journal of Experimental Zoology 249 316-321.

Schroeder JP \& Keller KV 1990 Artificial insemination of the bottlenose dolphin. In The Bottlenose Dolphin, pp 447-460. Eds S Leatherwood \& RR Reeves. San Diego: Academic Press.

Seager S, Gilmartin W, Moore L, Platz C \& Kirby V 1981 Semen collection (electroejaculation), evaluation and freezing in the Atlantic Bottlenose dolphin (Tursiops truncatus). Proceedings of the American Association of Zoo Veterinarians 13136.
Squires EL, Heesman CP, Webel SK, Schideler RK \& Voss JL 1983 Relationship of regumate to ovarian activity, hormone concentrations and fertility in mares. Journal of Animal Science 56 901-910.

Steinman KJ, Monfort SL, Jensen E, Sweeney J \& Robeck TR 2003 The use of mobile endocrine laboratory to assess reproductive status and time artificial insemination in captive cetaceans. Proceedings. International Association for Aquatic Animal Medicine 34 45-49.

Steinman KJ, O'Brien JK \& Robeck TR 2007 Characterization of reproductive cycles and development of an ovulation induction method in the beluga (Delphinapterus leucus). Proceedings. International Association for Aquatic Animal Medicine 38 162-164.

Taussky HH 1954 A microcolorimetric determination of creatine in urine by the Jaffe reaction. Journal of Biological Chemistry 208 853-861.

Turvey ST, Pitman RL, Taylor BL, Barlow J, Akamatsu T, Barrett LA, Zhao X, Reeves RR, Stewart BS, Stewart BS et al. 2007 First humancaused extinction of a cetacean species? Biology Letters 3 537-540.

Urian KW, Duffield DA, Read AJ, Wells RS \& Shell ED 1996 Seasonality of reproduction on bottlenose dolphins, Tursiops truncatus. Journal of Mammalogy 77 394-403.

Walker WA, Leatherwood JS, Goodrich KR, Perrin WF \& Stroud RK 1986 Geographical variation and biology of the Pacific white-sided dolphin, Lagenorhynchus obliquidens, in the north-eastern Pacific. In Research on Dolphins, pp 441-456. Eds MM Bryden \& R Harrison. Oxford: Oxford University Press.

Walker LA, Cornell L, Dahl KD, Czekala NM, Dargen CM, Joseph BE, Hsueh AJW \& Lasley BL 1988 Urinary concentrations of ovarian steroid hormone metabolites and bioactive follicle stimulating hormone in killer whales (Orcinus orca) during ovarian cycles and pregnancy. Biology of Reproduction 39 1013-1020.

Webel SK \& Squires EL 1982 Control of the estrus cycle in mares with regumate. Journal of Reproduction and Fertility Supplement 32 193-198.

Wildt DE 1992 Genetic resource banking for conserving wildlife species: justification, examples and becoming organized on a global basis. Animal Reproduction Science 28 247-257.

Wildt DE, Rall WF, Critser JK, Monfort SL \& Seal US 1997 Genome resource banks: living collections for biodiversity conservation. Bioscience 47 689-698.

Young SJF \& Huff DG 1996 Fertility management in a female killer whale (Orcinus orca) with regumate (Regu-mate). Proceedings. International Association for Aquatic Animal Medicine 2766.

Received 19 December 2008

First decision 18 February 2009

Revised manuscript received 22 May 2009

Accepted 2 June 2009 